\title{
Determinants of Rice Production and Marketing in low Producer Farmers: the Case of Fogera Districts, North-Western Ethiopia
}

\begin{abstract}
Astewel Takele
Department of Agricultural Economics, College of Agriculture and Environmental Sciences. Bahir Dar University, Ethiopia.

Abstract - Ethiopia is emerging as an important rice growing country in Eastern Africa. However, there are several constraints which drastically affect rice production and its marketing system under smallholder farmer's condition. This study aimed at examining the socioeconomic determinants of rice production and marketing in low producer farmers in the study area. A sample of 160 rice producer and 50 traders were interviewed using structured questionnaire. The result of the study showed that sex of household head is positive and statically significant in explaining rice production at 5\% significant level $(p<0.05)$. Oxen ownership $(p<0.07)$ and land size $(P<0.067)$ were directly proportional to rice production and significant at $10 \%$ level of significance respectively. Moreover, labor availability and rice seed rate was highly significant at $1 \%$ level of significance $(p<0.001)$. It is recommended that farmers should use intensive farming by increasing productivity of the land using improved varities, application of other alternative traction power(oxen), adopting labor saving technology and management of seed rate (agronomic practices)during sowing. Moreover, there is a need to consider gender differentials in rice production system. The $S$-C-P-model reflects that the structure of rice marketing is imperfect market (oligopsonistic), only few buyers governed the market. The Gross marketing margin indicated that assemblers harvest the highest marketing margin as compare to other market participants and farmers received below the total average share of the margin. High investment capital, and competition with unlicensed traders were the barrier in rice marketing. Hence, facilitating loan (credit services), increasing the bargaining power farmers \& licensing illegal traders were the recommendation forwarded.
\end{abstract}

Keywords - Rice, marketing, concentration ratio, S-C-P model, Ethiopia.

\section{BACKGROUND}

Rice (Oryza Sativa Linu) is the staple food of over half the world's population and at least 3.5 billion people are consuming the rice (Sreepada and Vijayalaxmi , 2013). It is one of the market oriented and strategic crop in the rice producing areas of Ethiopia. It was is a productive crop next to maize in the country (CSA, 2003) and considered as the "millennium crop" which is expected to contribute to ensuring food security in Ethiopia (Hadush, 2015, ). Rice was first introduced in Ethiopia in the 1970s and has been cultivated in small pockets of the country today (Yemane, 2014). The area under rice production in Ethiopia is estimated to have increased from 5,400 ha in 1993 to about 46,832 ha in 2014 (FAOSTAT, 2017). The number of farmers engaged in rice production has also increased from about 53 thousand in 2006 to about 284 thousand in 2009 (MoARD, 2010). 


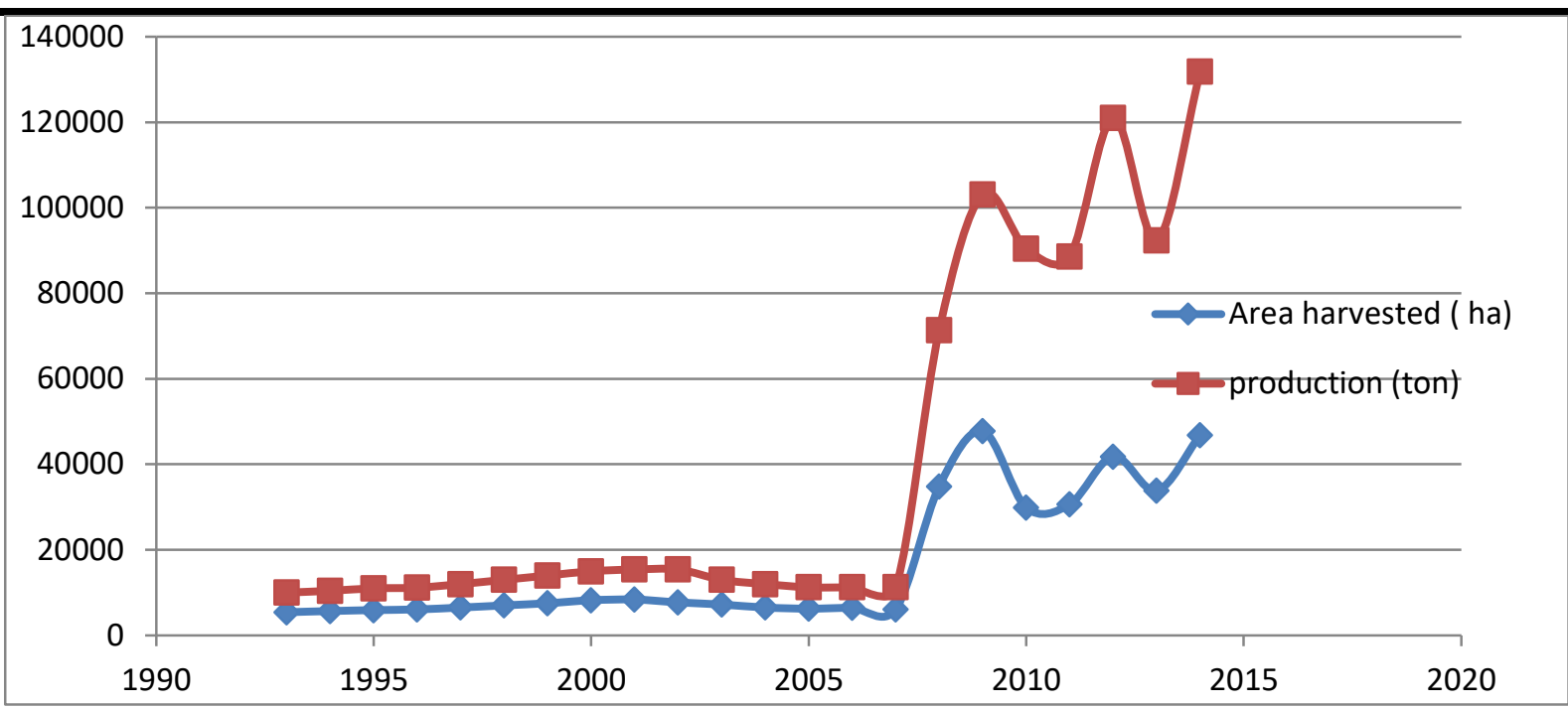

Fig.1: Area and production trend of rice in Ethiopia. Source: FAOSTAT, 2017.

The production of rice started in Amhgara Region at Fogera plain and at Gambella in Ethiopia. In the Fogera districts (where this research conducted) its production in hectare has been increasing year after year (CSA, 2013) and Fogera plain contributes about $32 \%$ of rice production in the country (EIAR, 2011). Efforts have made to boost production and productivity of rice through research for the last decades, however still different production and marketing factors hindered and limited its output production. Limited input supply, farmer's inefficiency, poor adoption of technology and institutional limiting factors (credit, market, etc) and other policy issues were among the variables were considered in farming system.

Improvement in production alone was not sufficient to achieve better income unless the marketing aspect as well improved. The marketing gap enforces farmers not produce rice as much as the potential beyond fulfilling their daily consumption. It is clear that markets offer households the opportunity to specialize according to comparative advantage and thereby enjoy welfare gains from trade (Reardon et al., 2005) but on the process of transaction the flow of agricultural produce from the producer to the consumer involves a long chain of intermediaries in Ethiopian grain marketing in general (Dawit, 2005, Gebremeskel etal., 1998.).

In the study area, Gebremedhin and Hoekstra (2007) studied that $72 \%$ of the households and about $50 \%$ of the farmers produce and sell rice; farmers sold and marketed its output into different regions of the country (IPMS, 2005). Also Afework, (2015) indicated that rice production in Fogera districts is constrained by seed production and marketing. Similarly inelastic price of the product and inefficient marketing system hinders the performance of the rice market. The involvement of many intermediaries has also constrained the development of the sector and deprived the farmers of equitable returns from their produces. The factor of rice production and lack of organized marketing system have resulted in low producers' price of farmers. This causes the farmers to declines its production in amount and marketable surplus would have an impact on the farmer's income ( for example for the last thirteen years from 1993 up to 2005 years ) the production and area coverage was very steady but since 2005 onwards for the last 10 years ( 2005-2014) production has increased rapidly (FAOSTAT, 2017). Therefore, understanding its production and marketing of rice as a whole (which supports over thousand million farmers livelihood) is vital for future production plan and policy development. In view of this, the study had been conducted specifically to analyze the factors that affect rice production, to assess the structure, conduct and performance of rice marketing and finally to identify the main channels of rice marketing in the study area.

\section{MATERIALS AND METHODS}

The study will particular try to address the following quest ions that are very important for planning and implementation of possible intervention policies.

\section{Research questions}

- What are the factors affecting rice production in the study area? 
- What are the structures of the rice marketing (who dominates the market), what are its behavior in price setting and their strategy for sales? Who benefit from the marketing of rice?

- What are the channels of distribution (roots) of rice marketing?

Study Area: Fogera districts is known for rice production and located on part of the South Gonder zone. The altitude of the district ranges from $1,500 \mathrm{~m}$ to 2,600 $\mathrm{m}$ above sea level while the annual average rainfall is $1,250 \mathrm{~mm}$. The district comprises of 18 rice producing peasant administrative (Kebeles). Out of which majority of it is suitable for lowland production of rice and few of it used in production of upland rice cultivation.

Sampling procedure or design: The data for this study collected from randomly selected from rice farmers in South Gondar zone (Fogera district). Purposive sampling technique used in the selection of rice producing Peasant Administrative (PA) in the districts. There are classified as rice- based farming system (PAs in which rice is dominant crop) and Cereal- based farming system (PAs in which non -rice crops) are dominant (IPMS, 2005). Among ten rice producing PAs in the districts, four of them were randomly selected based on the proportion to population size. A total of 120 samples were selected and used for the study. In addition to these marketing data were also collected from assemblers, wholesalers, millers and retailers in the market.

Types and source of data: The primary data were collected from a sample of rice producers and traders in the area by preparing structured questionnaire. A total of 165 producers were randomly selected and interviewed. In addition, secondary data were obtained from various sources, woreda trade and industry office, woreda agricultural office and Agricultural Research Centers.

Method of data Analysis: Both descriptive statistics, econometrics and structure- conduct and performance model (S-C-P model) were applied. The data were analyzed using Minitab-16 and SPSS-16 software's, the specification of the model is as follows:

Econometrics models. For this analysis econometrics models were applied. Using the ordinary least square (OLS) estimator, the production function model was estimated as follows:

$$
Y=\beta_{0}+\beta_{1} X_{1}+\beta_{2} X_{2} \cdot+\beta_{3} X_{3}+\beta_{4} X_{4}+\beta_{5} X_{5}+\beta_{6} X_{6} \ldots \ldots+\beta_{n} X_{n,}
$$

Where $\mathrm{y}=$ outputs

$\mathrm{X}_{\mathbf{n}=\text { explanatory variables }}$

$\beta_{0}=$ constant

$\beta_{n}=$ the parameters to be estimated

Structure- Conduct and Performance (S-C-P) model: It originates to the work of the Harvard economist Edward Mason in the 1930s. Mason (1939)'s starting point was that market share is important in determining production and pricing policy of a firm. The SCP approach analyzed the market organization of the industrial sector and it was later applied to assess the agricultural marketing system (Scarborough and Kydd, 1992). It comprises of three major elements: these are structure, conduct and performance. According to the structure-conduct-performance paradigm, the market environment has a direct, short-term impact on the market structure (Wikipedia, 2016)

Market Structure: Refers the characteristics of the organization of a market which seem to influence strategically the nature of the competition and pricing within the market (Bain, 1959). The way in which markets fail to follow perfect competition conditions. Also, the structure of the market will always be determined by the nature of the product and the technology available (Raj kumar, 2006). The most salient characteristics of market structure according to different writers (Scarborough and kydd , 1992) Scott, 1995, Clodius and Mueller, 1961 ) includes: 
1. The degree of seller's and buyer's concentration which refers to the number and size distribution of firms in relation to the size of the market;

2. The degree of the product differentiation among outputs of the various sellers in the market; and

3. Barriers to entry or freedom to entry and exit from the market: this refers to the conditions for entry of new firms into the market or exit of existing firms. There are many indexes/ instruments used to analyze ones firm structure of the market, among these are Concentration indexes, Herfindahl-Hirschma Index, Gini Coefficient and Lorenz curve.

Market concentration: is defined as the number and size of sellers and buyers in the market (Scott, 1995). The greater the degree of market concentration, the greater the possibility of non-competitive behavior in the market will be. Different literatures used different types of techniques to measure $d$ concentration. Concentration ratio is the percent of combined production of leading four or eight firms in industry. These can be explained as the four- firm concentration ratio (CR4), the four firm ratio of 51-80\% implies monopolistic competition and 81-100\% is high concentration -oligopoly or monopoly (Kohls and Uhl ,1985), (Karugia, 1991). In other words it can be measured by: (as expressed by Bedilu, etal., 2015, Khols and Uhl , 1985).

$$
C R_{4}=\sum \frac{X_{i}}{T}
$$

Where, $\mathrm{CR}_{4}$ concentration ratio of the first four dominant firms

$\mathrm{X}_{\mathrm{i}}$ is individual firm $\mathrm{i}$,

$\mathrm{T}$ is the total market size of firms.

Another popular measure of market structure of firm size is Herfindahl- Hirschman Index (HHI), means the percent of a individual sale potion in total sales and approaches zero when a market consists primarily of a large number of firms relatively equal in size ( kang etal., 2009). It is calculated by squaring the market share of each firm competing in the market and then summing the resulting numbers. In other words, it is equal to

$$
\mathrm{HHI}=\sum_{\mathrm{i}}^{4}(\text { marketshare })^{2}
$$

The HHI increases both as the number of firms in the market decreases and has the disparity in size between those firms' increases.. Markets in which the HHI is between 1000 and 1800 points are considered to be moderately concentrated and those in which the HHI is in excess of 1800 points are considered to be concentrated (monopoly). Another measure of market concentration is the Gini Coefficient (GC) approach named after the Italian statistician who first formulated it in 1912 (Todaro, 1998) and mathematically expressed as:

$$
G C=1-\sum X Y \text {, }
$$

Where,

$X=$ proportion of sellers,

$Y=$ cumulative proportion of sellers.

The value of the Gini Coefficient ranges between zero and one. The higher the coefficient, the higher the level inefficiency in the market structure (Giroh et al., 2010, Nsikan E. etal. , 2013) and Issahaku H. etal., 2012)

Additional method of computing concentration of market structure is Lorenz curves which can be used to provide a graphical overview of the distribution of market shares in an industry. The 45 degree straight line corresponds to equalized market shares. The Lorenz curve shows the quantitative relationship between the cumulative percentages of rice traders against the cumulative percentage of the volume of rice sold in the markets. To compute the cumulative percentage, the volume of rice sold will be arranged from highest to lowest. The Gini- coefficient or concentration ratio will be derived from the Lorenz curve. This measures the inequity in sales distribution among the different producer and trader groups (FAO, 2005). For this study, the concentration ratio is implemented as other methods are limited in their application for imposing additional restrictions. 
Market conduct: the set of competitive strategies that a trader or a group of traders use to run their business. It also explains that buying and selling practices are the variables which were used to determine the market conduct. Traders behavior like setting price individually or by colluding with each other and also if they jointly restricted the amount of rice for sale to raise the market price. In other words, market conduct focuses on traders' behavior with respect to various aspects of trading strategies such as buying, selling, transport, storage, information and financial strategy.

Market performance: market performance refers to the impact of structure and conduct as measured in terms of variables such as prices, costs, and volume of output (Bressler and King, 1979). It also refers to how well the market fulfils certain social and private objectives. The two major indicators of market performance are net returns and marketing margins. Estimating net returns and marketing margins provide indication of an exploitive nature when net returns of buyer are much higher than his fair amount. Net returns can be calculated by subtracting fixed and variable costs from gross returns, while marketing margin is defined as a difference between price paid by consumers and that obtained by producers or the price of collection of marketing services (Tomek and Robinson, 1990). By analyzing the level of marketing margins and their cost components, it is possible to evaluate the impact of the structure and conduct characteristics on market performance (Bain, 1968). The gross marketing margin and net marketing margin analysis is given as:

$$
\begin{aligned}
& \text { TGMM }=\frac{\text { consumer price }- \text { producer price }}{\text { consumer price }} \times 100 \\
& \text { GMMP }=\frac{\text { consumer price }- \text { marketing gross margin }}{\text { consumer price }} \times 100 \\
& \mathrm{NMM}=\frac{\text { Gross margin }- \text { marketing cost }}{\text { consumer price }} \times 100
\end{aligned}
$$

Where:

TGMM = Total Gross Marketing Margin

GMMP = Gross Marketing Margin of the Producer

NMM = Net Marketing Margin

Many researchers applied the SCP method for conducting their study on agricultural markets, However, the SCP method has been subject to criticism; e.g Scherer (1990) stated that the SCP model is too deterministic to understand the functioning of imperfect markets. As most agricultural markets are imperfect markets, we need to develop more dynamic models showing how structure, conduct and performance interact. Others also argued that the SCP school has emphasized the private exercise of market power as a source of poor market performance, but other economists have concluded that the main source of monopoly or anticompetitive is likely to be government interference in the marketplace. Finally the dynamic behaviors of buyers and sellers have an effect on the markets, making it harder to predict and establish fixed market structures.

\section{RESULT AND DISCUSSION}

Descriptive results of the study: showed that The major inputs used in the production of rice in the study area identified as land, labour, oxen (tropical livestock) unit/ herbicides and seed (described as table 1).

Land availability : Land happens to be one of the main inputs used in the study area for rice production. Land ownership in Ethiopia is state ownership. From the results of the descriptive statistics, the minimum land size is 0.12 hectare and the maximum is three hectares with the mean being 1.21 ha. This means that on the average people cultivate more than one hectare of land. It is clear that land ownership is found to be the main determinant factor that affects rice production in the study area.

Labour amount: Labour as an input is very important; The results of the survey showed that the maximum labour was 45 mandays with 2 man-days being the minimum and the mean labour in the study area was 12 man-days per year. The source of labour for the production was $44 \%$ family labour and $36 \%$ both family and hired labour. The Family size of the households has a mean of 6 in each household. It is also observed that labour amount of households significantly affect rice production. 
Seeds: Seeds are the paddy rice used for the production of rice. In the study area different varieties used for production, theses

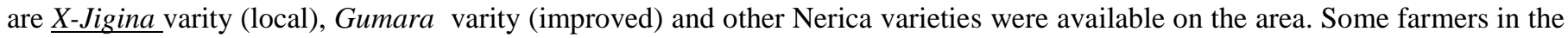
study area prepared their own seed, from the previous harvest whiles others buy from the market. On the average, farm households in study area uses a minimum rate of $15 \mathrm{~kg}$ per hectare and a maximum of $400 \mathrm{~kg} / \mathrm{ha}$ with average of $98 \mathrm{~kg} / \mathrm{ha}$ of seed respectively. The agronomic recommendation rate used in the area was 120 up to $140 \mathrm{~kg} / \mathrm{ha}$ of seed. The result from the econometric model also revealed that appropriate seed rate is the limiting factor for rice production.

Oxen ownership: oxen are one of the inputs used in rice production. it is the only traction power used for 300 years using local plough called Maresha ${ }^{l}$, the result of the survey shows that farmers has on average of two and a maximum of six pair of oxen respectively. There are also households without oxen and can be used as either rent in or hired oxen labor (specially female $\mathrm{HH}$ ) the area is known with its type of livestock breeds called Fogera breeds which is able to adopt for ploughing purpose in area where there is wet (marsh) area. It is also found that traction power using oxen is one of the inhibiting factors for rice production.

Fertilizer: The chemical fertilizer (DAP and UREA) are very important inputs used in the production of rice. Farmers use different rate of fertilizer application at different growing stage. In the study area only few farmers (highland area) farmers used fertilizer for rice production. Due to the area is near to the great Lake Tana, farmers less to apply fertilizer for growing rice production. Application of chemicals was not common in the study area and farmer used weeding by hand weeding than use of chemical control.

Table.1: Descriptive statistics of farm inputs in rice production.

\begin{tabular}{|c|l|l|l|l|l|l|l|l|l|l|}
\hline Description & & yield/ha & $\begin{array}{l}\text { Seed } \\
\mathrm{kg} / \mathrm{ha}\end{array}$ & $\begin{array}{l}\text { Family } \\
\text { labor } \\
\text { /AE/ }\end{array}$ & $\begin{array}{l}\text { Labor } \\
\text { amount } \\
\text { /year/ }\end{array}$ & $\begin{array}{l}\text { Oxen } \\
\mathrm{No} / \mathrm{HH}\end{array}$ & $\begin{array}{l}\text { UREA } \\
\mathrm{kg} / \mathrm{ha}\end{array}$ & $\begin{array}{l}\text { DAP } \\
\mathrm{kg} / \mathrm{ha}\end{array}$ & $\begin{array}{l}\text { Insecticide } \\
\text { lt/ha }\end{array}$ & $\begin{array}{l}\text { Herbicide } \\
\text { lt/ha }\end{array}$ \\
\hline $\mathrm{N}$ & Statistic & 165 & 155 & 165 & 164 & 165 & 164 & 163 & 164 & 164 \\
\hline Minimum & Statistic & 5.6 & 15 & 1 & 2 & 0 & 0 & 0 & 0 & 0 \\
\hline Maximum & Statistic & 112 & 400 & 6.15 & 45 & 6 & 25 & 10 & 9 & 3 \\
\hline Mean & Statistic & 31.17 & 98.03 & 2.68 & 12.21 & 1.91 & 0.43 & 0.06 & 0.08 & 0.16 \\
\hline $\begin{array}{c}\text { Std. } \\
\text { Deviation }\end{array}$ & Statistic & 17.74 & 128.37 & 0.88 & 11.17 & 1.04 & 2.62 & 0.78 & 0.72 & 0.44 \\
\hline Skewness & Statistic & 1.75 & 1.48 & 1.12 & 1.19 & 1.10 & 7.08 & 12.76 & 12.07 & 3.02 \\
\hline & $\begin{array}{c}\text { Std. } \\
\text { Error }\end{array}$ & 0.19 & 0.19 & 0.19 & 0.19 & 0.19 & 0.19 & 0.19 & 0.19 & 0.19 \\
\hline Kurtosis & Statistic & 3.96 & 2.83 & 1.57 & 0.44 & 2.66 & 55.56 & 163.0 & 150.72 & 11.73 \\
\end{tabular}

Source: Own Survey

\section{Econometric result of the study}

According to the econometric result (ordinary least square analysis) four variables were found to be significant, namely sex of households, oxen number, land size, amount of labour availability and seed rate. The result implied that gender (sex of $\mathrm{HH}$ farmers) is positively related to rice production and it was significant at $5 \%$ percent $(P<0.002)$ and land size is also positively related with the rice production and it is also at $10 \%$ level of significance $(P<0.067)$ and number of oxen ownership is more significant positively with rice production at $5 \%$ significant level $(P<0.07)$. In the production of rice, labour is highly significant at $1 \%$ level $(P<0.002)$, and it is the most binding factor among all variables, likewise amount of seed used in the production is also highly significant at $1 \%$ level $(P<0.002)$.

${ }^{1} \mathrm{~A}$ wooden and a metal made material used for oxen ploughing 
The overall analysis (ANOVAs) F-statistic shows that it is highly significant at $1 \%$ level $(P<0.000)$, showing that there is significant variation of rice production among predicted variables in the study area. The adjusted R-square is $21 \%$, it is showed that $21 \%$ of the variation is explained by the independent variables of the model under ceteris paribus assumption (other things held constant) and other variation is coming from external factors (exogenously).

Table.2: Factors (determinants) of rice production.

\begin{tabular}{|c|c|c|c|c|c|}
\hline \multirow[t]{2}{*}{ Model } & \multicolumn{2}{|c|}{$\begin{array}{l}\text { Unstandardized } \\
\text { Coefficients }\end{array}$} & \multirow{2}{*}{$\begin{array}{c}\text { Standardized } \\
\text { Coefficients }\end{array}$} & \multirow[t]{2}{*}{ t-statistics } & \multirow[t]{2}{*}{ Sig. } \\
\hline & $\mathrm{B}$ & Std. Error & & & \\
\hline (Constant) & -8.891 & 8.545 & & -1.04 & 0.300 \\
\hline Age of $\mathrm{HH}$ & -0.081 & 0.084 & -0.085 & -0.968 & 0.335 \\
\hline Sex of $\mathrm{HH}$ & $15.321 * *$ & 7.471 & 0.144 & 2.051 & 0.042 \\
\hline Education level of $\mathrm{HH}$ & 1.127 & 0.996 & 0.086 & 1.132 & 0.259 \\
\hline Family size of $\mathrm{HH}$ & 0.401 & 0.526 & 0.065 & 0.761 & 0.448 \\
\hline Amount of labour used & $0.243 * * *$ & 0.076 & 0.232 & 3.209 & 0.002 \\
\hline Oxen number & 0.931* & 0.51 & 0.133 & 1.825 & 0.07 \\
\hline Land size( ha) & 3.098* & 1.679 & 0.156 & 1.845 & 0.067 \\
\hline Amount of seed (qt.) & $0.037 * * *$ & 0.012 & 0.231 & 3.147 & 0.002 \\
\hline $\begin{array}{l}\text { a. Dependent Variable: } \\
\text { R-square }=0.257 \\
\text { Adjusted R-square }=0.2 \\
\text { F statistics }=6.687 * * * \\
\mathrm{~N}=163\end{array}$ & ddy rice pr & luced & & & \\
\hline
\end{tabular}

Source: own computation

\section{Problems Encountered by the Farmers.}

There are many problems encountered farmers during production in the study area one of it the problem of rice thresher (unavailability of appropriate machinery). For instance there was no rice thresher or miller in the nearby area (Peasant Administrative) and opt to travel along way near cities. Through direct observation it was realized that farmers lose a lot during harvesting when they used threshing by beating with stick. Majority of the interviewed (56\%) cited this problem. Farmers however, also claim that the varity of seed was few, they usually used local varity which is available in the area, commonly called X-Jigna varity.. Accessibility of roads that link the fields to the main roads is a problem cited by respondents especially during rainy season. finally capital shortage and price fluctuation were considered to be the problems in the study area.

\section{Market analysis of the study ( S-C-P -mode):}

Market structure: Even though different types of traders were available in the study sites market concentration ratio has been calculated for one trader to analyze the type of markets prevailed (Table 3). The results indicated that the structure of the market was measured by using concentration ratio (CR4), it was found that the four-firm Concentration ratio was about 0.77 for wholesale buyers. The concentration ratio of 0.77 indicates that $77 \%$ of the market volume was occupied by few buyers. Therefore; the market was governed by few wholesale buyers (i.e. strongly oligopsonistic). As Bain (1959), said the market structure has influence on the market conduct and this can be influence on the nature of competition and pricing within the market.

Table.3: Market concentration of rice wholesalers.(CR4-ratio)

\begin{tabular}{|c|c|c|c|c|c|}
\hline & \multicolumn{3}{|c|}{ Amount of rice purchase } & \\
\hline wholesalers' & qt/month & $\%$ share & Rank & 4 -firms & Main Destinations \\
\hline 1 & 2200 & 24.58 & $1 \mathrm{st}$ & $*$ & Addis Abeba, Wollo \\
\hline 2 & 1350 & 15.08 & 4 th & $*$ & Addis Abeba, Wollo \\
\hline
\end{tabular}




\begin{tabular}{|c|c|c|c|c|c|}
\hline 3 & 1750 & 19.553 & 2nd & $*$ & Addis Abeba, \\
\hline 4 & 1650 & 18.44 & 3rd & $*$ & Addis Abeba, \\
\hline 5 & 1250 & 13.97 & & & Addis Abeba \\
\hline 6 & 750 & 8.38 & & & Addis Abeba \\
\hline \multicolumn{2}{|l|}{ Concentration ratio (CR4 in \%) $=77.65$} & 100 & & & \\
\hline
\end{tabular}

Source: own computation

The Gini coefficient was also used to determine the market structure of the rice market. The market structure analysis for wholesalers reveals a Gini coefficient of 0.58 as table- 4 below. Since the coefficients are closer to one, the concentration of the market is relatively high indicating the existence of inefficiency in the market structure.

Table.4: Market Structure Analysis of Wholesalers.(GC)

\begin{tabular}{|l|r|r|r|r|r|r|}
\hline $\begin{array}{l}\text { Monthly Sales ETB } \\
\text { (000)@ price of } \\
708 / \mathrm{q}\end{array}$ & Number & Proportion(X) & $\begin{array}{l}\text { Cumulative } \\
\text { proportion }\end{array}$ & $\begin{array}{l}\text { Monthly sales } \\
\text { ETB }^{2} \text { (000) }\end{array}$ & $\begin{array}{l}\text { Prop. of cum. } \\
\text { Total sales (Y) }\end{array}$ & XY \\
\hline$<800$ & 1 & 0.17 & 0.17 & 531 & 0.08 & 0.01 \\
\hline $800-1,000$ & 2 & 0.33 & 0.50 & 1840.8 & 0.29 & 0.10 \\
\hline$>1,000$ & 3 & 0.50 & 1.00 & 3964.8 & 0.63 & 0.31 \\
\hline Total & 6 & - & - & 6336.6 & - & 0.42 \\
\hline GC=1- $x \mathrm{xy}, 1-0.42=0.58$
\end{tabular}

Source: own computation

\section{Barriers to entry in rice market are:}

Investment capital: Another factor affecting the market structure is entry and exit barriers. To enter in the rice market initial capital investment is one of the barriers observed in the area that means more capital (demands more money) is an entry barrier to enter to the rice market. It is needed to handle more quantity of rice (during peak period) as its unit price is very high when compared to the other commodities.

Trader license: The barriers associated with assemblers on top of the regulatory framework require a trader's license from the government office. The cost of the license depends on the type of license and the total sales volume of trader. Many traders (as par time business) also indicated that high taxation rate forced traders working without licensing. Hence competition with unlicensed traders became a barrier to enter into rice marketing in general. .

Experience and price information: it was observed that about $69 \%$ of the sampled households had price information access (knowledge ) of the nearby market price before they sold their output. Hence unless it's spontaneous fluctuation, price information of the commodity was not barrier for them. The survey result indicate that about $47 \%$ of the respondents had experience in rice trading between 2-5 years, $40 \%$ of them had experience of six up to ten years and the rest $6.7 \%$ had above 21 years of experience respectively.

Market conduct: in the study area there were no traders who specialized in rice trading but they were grain traders in general. During the study many occasional traders purchase $\mathrm{d}$ target during peak harvest times. Most grain traders were licensed and some other were trading rice without license (assemblers and brokers). Market traders can be characterized from the point of rice trading into producers, millers, retailers, urban distributors, urban and rural assemblers. The survey result indicated that most of the time wholesalers and millers buy $80 \%$ of rice from Woreta market (on their ware house) and $20 \%$ from village market. The reason to stay more in that area was due to high supply. The purchasing strategy for wholesalers was based on the long term

\footnotetext{
2 Ethiopian birr
} 
client establishment, infra- family link and spontaneous purchasing. About 53\% of sample traders indicated that price was set by the market but $27 \%$ of them were setting prices by themselves (price makers), $13 \%$ set by negotiation of buyer and traders and few $(7 \%)$ of them set market price by getting information from the District Agriculture office.

Performance of rice marketing: The two major indicators of market performance are net returns and marketing margins. Estimating net returns and marketing margins provide indication of an exploitive nature when net returns of buyer are much higher than his fair amount. (Table-4) below gives an overview of distribution of marketing margin among different actors in the channel. The total gross marketing margin (complete distribution channel) was about 54\% and the farmer's market participation was found to be $46 \%$ which is below the average percent share. Rural assemblers get the highest gross marketing margin compare to the other market participants.

Table.4: Summary of Gross marketing margins of traders in rice marketing.

$\left.\begin{array}{|l|l|c|c|c|}\hline & \text { Market participants } & \begin{array}{c}\text { Buying price } \\ \text { (average) }\end{array} & \begin{array}{c}\text { selling price } \\ \text { (average })\end{array} & \begin{array}{c}\text { Gross marketing margin (GMM) } \\ \text { ( }\end{array} \\ \hline \text { i } & \text { Farmers }\end{array}\right)$

Note: ${ }^{1} T G M M=$ End buyer price - first seller price $/$

End buyer price (the terminal market)

Rice marketing channels: The rice marketing, from producer to consumer, is a complex process involving handling from multiple intermediaries. There are three separate levels of marketing as shown in Figure 2: These are four main types of channels in consumers' markets, zero-level, is the simple one in which goods flow directly to the end-users., One level in which one intermediary in between, and multilevel in which two and more than two intermediaries in between (Amarchand and Varadharajan, 1979). The major receivers of rice from farmers were, wholesalers (45\%), Millers (27\%), rural assemblers (14\%) and urban collectors (12\%) in order of volume of purchase respectively. 


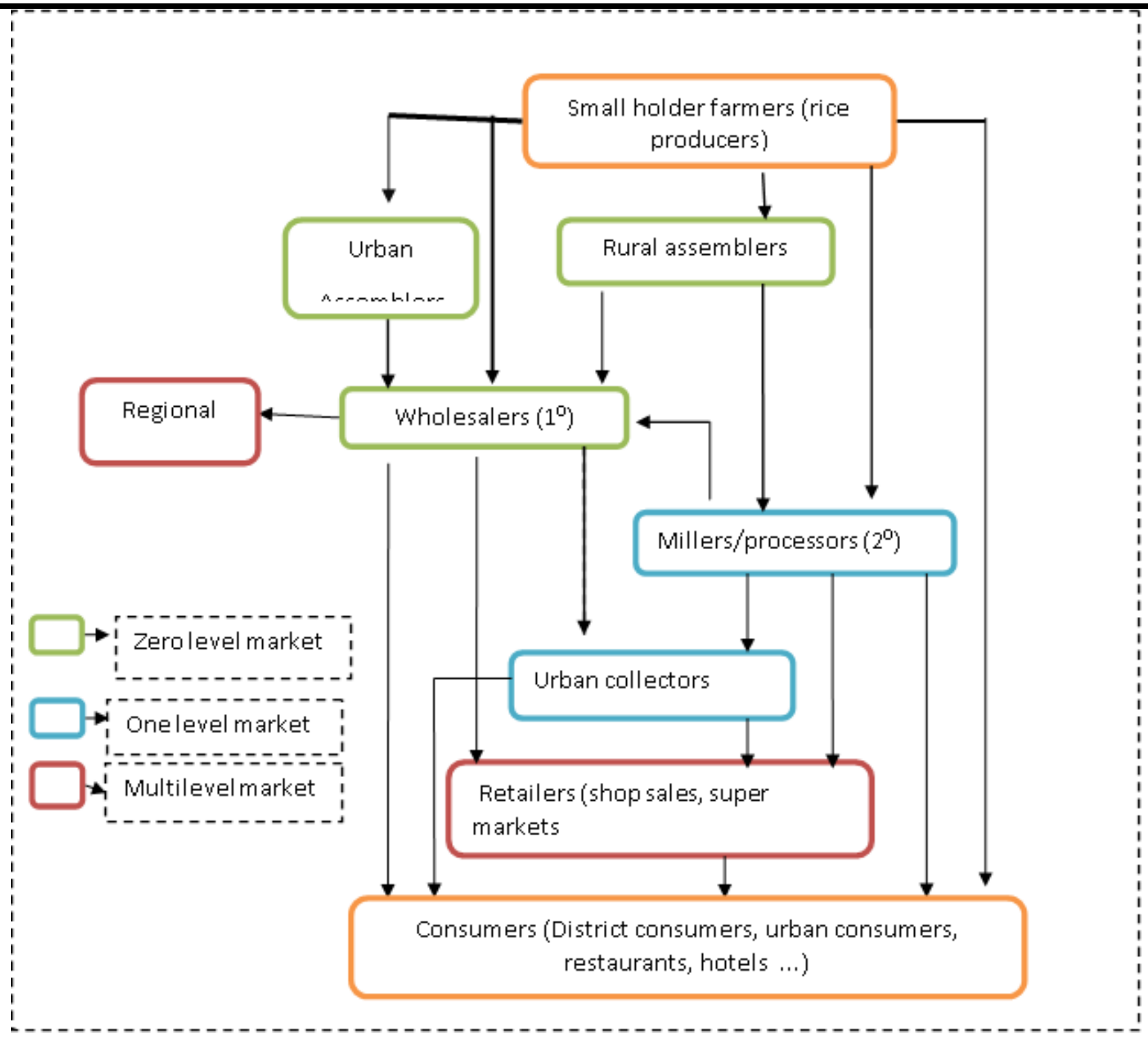

Fig.2: Rice marketing channels in Fogera Districts.

\section{CONCLUSIONS}

In general, the following conclusions were derived from this study:-

- Sex of households, labour amount, oxen number, Land size and seed rate were the main socio economic factors that determines rice production in the study area .

- The rice market structure revealed that there is imperfect (uncompetitive) market environment among rice traders. The structure was strongly oligopsonistic i.e the market was governed by few wholesalers' (buyers).

- The barriers to enter to the market were investment capital, prior control of farmers or clients and competition with unlicensed traders. Marketing margin analysis indicated that rural collectors (assemblers) get higher gross market margin as compare to other market participants in the rice trade farmers obtain below the average.

- In the rice marketing chain the main rice receivers in the channel were wholesalers $\left(1^{\text {st }}\right)$, Millers $\left(2^{\text {nd }}\right)$, rural assemblers $\left(3^{\text {rd }}\right)$, and urban assemblers respectively.

- Rural assemblers were found to harvest the higher marketing margin from all the marketing participants and farmers portion were obtain below the average percentage share of the gross marketing margin. 
- The common problems identified in rice production and marketing were to be lack of miller machine, shortages of seed varity and its rate of application by the farmers, transportation facilities, investment capital and price fluctuations were found to be the main one.

\section{Recommendations}

* Market intervention to make the market competitive (increase the bargaining power of farmers) e,g linkage formation to Ethiopian commodity marketing system (ECX)

* Use of intensive farming, developing varities with agricultural researchers specially lowland and high land varity

* Adoption of alternative traction power (like two wheel tractor) and introducing labour saving technology.

* Demonstration of appropriate seed rate application to farmers

* Considering gender differences during rice cultivation system.

* Credit facilities for capital investment and awareness creation on importance and use of licensing trade

\section{REFERENCES}

Afework Mesfin, 2015. Improved Rice Seed Production and Marketing: Challenges and Opportunities the Case of Fogera istrict of Ethiopia.

Bain, J.S., 1959, 1968. Industrial organization $1^{\text {st }}$ and $2^{\text {nd }}$ Edition .New Yourk.Johnwiley.

Birhanu G. and Hoekstra .D.,2007. Cereal marketing and household market participation in Ethiopia: the case of teff, wheat and rice. Proceeding of the $2^{\text {nd }}$ AAAE Conference. Accra, Ghana. Pp243-252.

Central Statistics Authority, (CSA) 2003. Statistical Report on Area and production of crops.part II-A. Addis Ababa, Ethiopia Central statistical Agency (CSA), 2013. Agricultural sample survey 2012/ 2113, volume III. Report on area and production, Addis Ababa, Ethiopia.

Dawit A., 2005. The status and challenges of agricultural marketing in Ethiopia PP.1, Paper presented at a panel discussion organized by the Ethiopian Association of Agricultural Professionals (EAAP), April 22, 2005.Ethiopian Agricultural Research organization (EARO).

Ethiopian Institute of Agricultural Research (EIAR), 2011. Empowering Farmers' Innovation, Series No.2: Challenges and Opportunities of Rice in Ethiopian. Agricultural Development, Adise Abeba, Ethiopia.

Food and Agriculture Organization of the United Nations (FAO), 2004. Charting Income Inequality -The Lorenz Curve.

FAOSTAT (Food and Agriculture Organization of the United Nations) , 2017. Accessed in www.fao.org/faostat/en/\#data/QC

Getachew A. 2000. Rice adaptation in Metema District North Gondar one of the Amhara Regional State", Bureau of Agriculture, Bahir Dar.

Giroh, D.Y, Umar, H.Y \& Yakub, W., 2010. African Journal of Agriculture Research. Structure, Conduct and Performance of Farm Gate Marketing of Natural Rubber in Edo and Delta States, Nigeria. 1.5 (14), 1780-1783.

Gebremeskel D, T.S. Jayne, J.D. 1998. Shaffer working paper 8 grain market research project ministry of economic development and cooperation Addis Ababa January 1998.

Gebremeskel D., Jayne T.S., ShafferJ.D., 1998. Market structure, Conduct, and performance: Constraints on performance of Ethiopian grain markets. Working paper 8 Grain market research project Ministry of economic development and cooperation Addis Ababa January 1998

Hadush H., 2015. Production of Upland Rice and Constraints faced by the Farmers in Tselemti District, Northern Ethiopia. Journal of Poverty, Investment and Development Vol.19, 2015

Improving Productivity and Market Success of Ethiopia (IPMS), 2005. Fogera Wereda pilot learning Site Diagnosis and Program Design

Issahaku H., Paul K. N. Yazidu U., 2012. Structure, Conduct and Performance of Tomato Marketing in Ghana. Journal of Economics and Sustainable Development. Vol.3, No.10, 2012.

IFPRI, 2010. Pulses Value Chain in Ethiopia: constraints and opportunities for enhancing exports. Working Paper, July. IFPRI, Washington, DC.

Jeff E. Biddle, 2010 . The Introduction of the Cobb Douglas Regression and its Adoption by Agricultural Economists . Dept. Of Economics Michigan State University. October, 2010. 
Kizito A., 2008. Famine early warning systems net work (FEWS NET) market Guidance”, No.2, Structure -ConductPerformance and food security.

Karugia, J.T., 1990. Competition and efficiency in beef retailing in metropolitan area; the case study of thee city of Nairobi., Ph.D. Thesis, University of Nairobi.

Kohls, R.L., and J.N. Uhl, 1985. Marketing of Agricultural Product”, Fifth Edition., McMillian Publishing Company, New York, USA.

Kang H., Kennedy P.L, and Brian Hilbun B. ,2009. Structure and conduct of the world rice market. Southern Agricultural Economics Association Annual Meeting, Atlanta, Georgia, January 31-February 3, 2009.

Ministry of Agricultural and Rural Development (MoARD), 2010. National Rice Research Development Strategy of Ethiopia" Mason E.S., (1949), The current state of the monopoly problem in the United States, Havard Law Review, Vol. 62, pp.1265-85.

Nambiro, E., Groote H.D. .and Kosura. W. O., 2001. Market structure and conduct of the hybrid maize seed industry, a case study of the Trans Nzoia district in western Kenya, Seven Western and Southern Africa Regional Maize Conferences $11^{\text {th }}-15^{\text {th }}$ February, 2001. PP.474-479

Nsikan Edet Bassey, Otu William Ibok, Aniekan Jim Akpaeti. 2013. Asian Journal of Agricultural and Food Sciences. Vol.1 (3) .2013.

Paulos Desalnge, 2004. Growth, direction and structure of Ethiopian coffee exports, Alemaya University

Rice Market Structure, Conduct and Performance in Nigeria: A Survey of Akwa Ibom State Rice Marketers.

Scott, G.J., 1995. Prices, Products and People, Analyzing Agricultural Markets in Developing Countries. Lynne Reinner Publishers, Boulder, London. 498p.

Sreepada H. and Vijayalaxmi H., 2013. Assessment of Global Rice Production and Export Opportunity for Economic Development in Ethiopia. International Journal of Science and Research (IJSR), India. Volume 2 Issue 6, June 2013

Scarborough, Vanessa and Kydd. 1992. Economic Analysis of Agricultural Markets: A Manual Marketing Series 5, Chatham, UK: Natural Resource Institute. 172p.

Todaro, M. 1998. Economic Development. 6th edition New York.

Tomek, W.G. and Rrobison, K.L. 1990. Agriculture product prices.3rd Edition. Cornel University Press. Ithaca and London. https://en.wikipedia.org/wiki/Structure,conduct and performance paradigm, October 2016.

Yemane A., 2014. Determinants of adoption of upland rice varieties in Fogera district, South Gondar, Ethiopia. Journal of Agricultural Extension and Rural Development. Vol.8(12), pp. 332-338 October, 2014. 